\title{
ע Nuorten mielenterveyspalvelut - määrä, tarjonta ja kohdentuminen Uudenmaan alueella
}

Nuorten pahoinvointi on ollut keskeisenä huolena viïmeaikaisessa tutkimuksessa ja julkisessa keskustelussa. Erityisesti lastensuojelun asiakaslapsille kasautuu paljon kuormittavia tekijöitä. Nuoria lähellä olevat palvelut sekä varhainen puuttuminen ovat tehokkaimpia lisäämään yhteiskuntaan kïnnittymistä. Suomessa on käynnissä laaja palvelurakenneuudistus, mutta muutoksen tueksi tarvittava tutkimustieto on kuitenkin puutteellista.

Tutkimuksessa kuvataan nuorten mielenterveyspalveluita Uudenmaan alueella vuonna 2014. Kaikki Uudenmaan alueen nuorille tarkoitetut mielenterveyspalvelut kartoitettiin ja toiminnot luokiteltiin nuorille sovelletulla ESMS-R-työkalulla. Palveluita tarkastellaan lukumäärän, monipuolisuuden ja avohoidon henkilöstöresurssien perusteella sekä suhteutetaan lastensuojelun asiakasnuorten määrään.

Nuorten hyvinvoinnin riskitekijät ja palveluiden monipuolisuus korreloivat alueen väkiluvun kanssa. Avohoidon henkilöstön resursointi ei ollut suhteessa väkimäärään, lastensuojelun avohuollon asiakkaisiin tai kodin ulkopuolelle sijoitettuihin. Lisäksi monilla alueilta puuttuivat kokonaan esimerkiksi päivätoimintojen ja liikkuvan avohoidon palvelut.

Tarkastelun perusteella alueen nuorten mielenterveyspalveluiden avohoito vaikuttaisi eriarvoiselta ja sattumanvaraiselta. Tulokset ovat tarpeen suunniteltaessa palveluiden kehittämistä siten, että kaikilla nuorilla on tarjolla yhtäläisiä palveluita kotikunnasta riippumatta. Nämä asiat tulisi huomioida myös tulevassa sosiaali- ja terveyspalveluiden uudistuksessa.

ASIASANAT: nuoret, mielenterveyspalvelut, lastensuojelu, julkiset
palveluntuottajat

JOHANNA HEDMAN, MARJUT VASTAMÄKI, GRIGORI JOFFE

\section{JOHDANTO}

Suomessa syntyi 80-luvun loppupuolella ikäluokka, jonka nuoreksi aikuiseksi kasvamista ovat varjostaneet kaksi lamaa ja hyvinvointipalveluihin kohdistuneet leikkaukset 90-luvun alusta alkaen. Vuonna 1987 syntyneiden hyvinvointia on tarkasteltu laajaan rekisteriaineistoon perustuvilla tutkimuksilla. Yhteiskuntaan kiinnittymises- sä on todettu tulosten perusteella olevan suuria haasteita erityisesti niillä nuorilla aikuisilla, jotka ovat olleet kodin ulkopuolelle sijoitettuina - lastensuojelun viimesijaisen tuen piirissä on ollut 3,2 prosenttia ikäluokasta. Lisäksi kohorttiaineiston tulokset osoittavat mielenterveyshäiriöiden olevan yllättävän yleisiä. Tutkimusten mukaan noin joka viides vuonna 1987 syntyneistä oli saanut 
hoitoa tai lääkitystä psyykkisiin ongelmiin. Psyykenlääkkeiden ja avohoitopalveluiden käyttö osoittivat seurannassa vielä kasvua. $(1,2$.)

Näiden tutkimusten tulokset lisäsivät huolta lasten, nuorten ja nuorten aikuisten hyvinvoinnista Suomessa. Huoli koskee vahvasti ennen kaikkea nuorisoikäisiä (13-17 -vuotiaita), joiden huonovointisuus näkyy niin mielenterveys- kuin lastensuojelutilastoissakin. Vastaavia tuloksia on saatu myös kansainvälisissä tutkimuksissa (3): käytös- ja tunne-elämän häiriöt nuorilla ovat kasvaneet. Murrosiän alkaminen, yläkoulu ja muutosvaiheet lapsuudesta aikuisuuteen asettavat nuoret tilanteisiin, joissa mielenterveyden haasteet saattavat puhjeta.

Erityisesti lastensuojelun kodin ulkopuolelle sijoittamilla nuorilla on riski ongelmien kasautumiselle. He myös käyttävät paljon viimesijaisia, kalliita palveluita (4). Kodin ulkopuolelle tehtyjen sijoitusten taustalta löytyy usein nuorten mielenterveysongelmia $(5,6)$. Niihin ei aina vastuusosiaalityöntekijöiden arvion mukaan ole saatu riittävästi psykiatrian palveluita tai osaamista (7).

Hoitamattomat mielenterveyshäiriöt näkyvät yhteiskunnassa monella tasolla. Ne ovat inhimillisen pahoinvoinnin lisäksi myös merkittävä kansantaloudellinen haaste, niin välillisten kuin suorienkin kustannuksien kautta. Mielenterveyden häiriöille altistavat tekijät ja niiden seuraukset ovat hyvin tunnistettuja. Esimerkiksi perhesuhteiden kuormittavuus, sosiaaliset tekijät ja taloudellinen niukkuus vaikuttavat nuorten mahdolliseen sairastumiseen. (5). Perheessä olevien stressitekijöiden on todettu olevan yhteydessä nuorten palveluntarpeeseen sekä avun hakemiseen. (8). Useiden tutkimusten mukaan $(1,2,5,7,9)$ mielenterveysongelmat ovat vahvasti yhteydessä esimerkiksi kouluttautumiseen, kehitykseen, päihteidenkäyttöön, väkivallan käyttöön tai uhriksi joutumiseen sekä seksuaaliterveyden riskeihin.

Lisäksi hoitamattomina ja pitkään jatkuneina mielenterveysongelmat altistavat itsemurhariskille. Uudessa-Seelannissa toteutetussa tutkimuksessa (10) todettiin, että nuorten itsemurhia ehkäistään parhaiten siten, että tuki tarjotaan nuorille heidän omassa ympäristössään. Suomessa on tarkasteltu (11) täysi-ikäisille suunnattujen avohoitopalveluiden suhdetta itsemurhien määrään: laajat avohoidon palvelut ja monipuoliset, päivystävät avopalvelut sekä kunnan panostus avohoidon resursointiin näyttäisivät vaikuttavan itsemurhien määrään vähentävästi. Vaikka Suomessa mielenterveysongelmista kärsivien kuolleisuusaste onkin pienentynyt, tulisi vielä jatkossa keskittyä erityisesti julkisten ja kunnallisten palveluiden tarjonnan kehittämiseen sekä ennaltaehkäisyyn. (12.)

Nuoruusiässä alkavat mielenterveysongelmat tulisikin tunnistaa mahdollisimman varhaisessa vaiheessa oikean hoidon löytämiseksi. Monet oireet ilmaantuvat ensimmäisiä kertoja 12-14 vuoden iässä, mutta niiden tunnistaminen ja hoitoon hakeutuminen tapahtuu usein huomattavasti myöhemmin. Ajoissa kohdennetulla avulla olisi mahdollista parantaa nuorten kiinnittymistä yhteiskuntaan ja esimerkiksi pääsyä työelämään. Oikea-aikaisella ja avulla mahdollistetaan nuorten oman toimintakyvyn kehittyminen ja elämässä selviytyminen. $(9,12,13$.) Nuoret ottavat apua hakiessaan yhteyttä useisiin toimijoihin ja etsivät neuvoa eri paikoista. Avuntarjoajiksi koetut paikat voivat olla ongelmallisia, jos niissä ei ole resursseja tunnistaa tai hoitaa mahdollisia mielenterveysongelmia. $(9,14,15$.)

Palveluiden järjestämisessä tulisikin painottaa aikaisia interventioita, ennakoivia palveluita sekä pääoireiden varhaista tunnistamista. Alkuvaiheen oireiden kohdalla jopa oikein kohdennettu oma-apu voi olla riittävää. $(9,16)$. Asiakkaan kannalta merkityksellistä ei niinkään ole toiminnon tuottaja ja kustantaja, vaan pääsy tarvittavan palvelun piiriin sekä hoidon sisältö (17). Monipuolisten avohoitopalveluiden tarjonnan voidaan ajatella tarkoittavan asiakaslähtöistä hoitoa ihmisen tarpeiden mukaan (11).

On todettu, että yhtäläinen pääsy mielenterveyspalveluihin on tärkeää ja sen tulisi olla sosiaali- ja terveyspolitiikan keskeisenä periaatteena (18). Sosiaali- ja terveyspoliittiset ratkaisut on tehty kunnissa pitkälti mielipiteiden ja poliittisen ajattelun perusteella, koska nuorten palvelujärjestelmää koskeva tutkimustieto on ollut riittämätöntä.

Palvelujärjestelmä on muodostunut nuorten kannalta myös pirstaleiseksi. Mielenterveysongelmaisia nuoria pyritään auttamaan niin kunnallisessa sosiaali- ja terveydenhuollossa kuin alueellisessa erikoissairaanhoidossa, ja lisäksi myös järjestöt ja yksityiset palveluntuottajat tarjoavat erilaisia palveluita. Moniportaisen järjestelmän on nähty yleisesti vaikeuttavan avun saamista nopeasti ja oikea-aikaisesti. Myös rajat 
eri toimijoiden hallintojen sekä budjettien välillä ovat asettaneet haasteita saumattoman avun järjestämiseksi. (19.)

Sektoroituneeseen palvelutarjontaan on pyritty vastaamaan erilaisilla hankkeilla ja palvelujärjestelmää kehittämällä. Tällä hetkellä on käynnissä laaja sosiaali- ja terveydenhuollon palveluiden uudistaminen, joka linkittyy vahvasti maakuntahallinnon perustamiseen. Lisäksi käynnissä on lapsi- ja perhepalveluiden muutosohjelma (LAPE), jossa uudistetaan muun muassa mielenterveys- ja lastensuojelupalveluita nuorille sekä heidän perheilleen. Muutosohjelmassa korostetaan saatavuudeltaan ja laadultaan yhdenvertaisia palveluita sekä tavoitellaan valtakunnallisesti yhtenäisiä kriteerejä palvelutarjontaan. (20.)

Palvelutarjonnan eriarvoisuus on todettu täysi-ikäisten kohdalla. Palvelut vaikuttavat olevan monipuolisempia väestömäärän, ei niinkään alueen tarveindikaattorien perusteella. (21.) Samoin psykiatrisen erikoissairaanhoidon käyttöön on nähty vaikuttavan perheen asuinpaikka ja sosioekonominen asema (18). Vaikka aikuisten hyvinvointi ja mielenterveys vaikuttavat perheen lasten ja nuorten hyvinvointiin $(5,9,22)$, ei nuorten hyvinvoinnin tarpeista tai palveluiden kohdentamisesta ole tehty Suomessa kattavaa, vertailukelpoista tutkimusta. Alueelliset tiedot väestön sairastavuudesta sekä palveluiden resursseista, rakenteista, kustannuksista, tuottavuudesta ja vaikuttavuudesta ovat hajautuneet eri organisaatioiden tietokantoihin, joten niiden kattava ja järjestelmällinen keruu on ollut haastavaa.

\section{TUTKIMUKSEN TAVOITE}

Tämän tutkimuksen tavoitteena on tuottaa rakenteellista tietoa päätöksenteon tueksi. Tutkimuksessa selvitetään ja kuvataan nuorten mielenterveyspalveluita Uudenmaan alueella vuonna 2014. Käytettyyn aineistoon on kerätty samaan tietokantaan perusterveydenhuollon, erikoissairaanhoidon sekä kolmannen sektorin tarjoamat mielenterveyspalvelut, mikä mahdollistaa niiden laajan vertailun. Palveluita tutkitaan sekä niiden lukumäärän että monipuolisuuden suhteen ja lisäksi tarkastellaan henkilöstön resursoinnin painotusta palveluissa.

Tutkimus tarkastelee niitä palveluita, jotka on kohdennettu erityisesti nuorten mielenterveyden turvaamiseksi. Vaikka on tiedossa, että lastensuojelun avohuollossa on asiakkaana runsaasti psyykkisesti oireilevia nuoria, ei lastensuojelun avopalveluiden voida ensisijaisesti ajatella olevan psykiatrian tai mielenterveysongelmien hoitoon kohdennettuja. Mielenterveyden pulmista kärsiviä nuoria sijoitetaan yhä enemmän kodin ulkopuolelle, joten tässä tutkimuksessa on mielekästä tarkastella sijaishuoltopaikkoja osana nuorille suunnattuja mielenterveyspalveluita.

Tutkimuksessa selvitetään vastauksia seuraaviin kysymyksiin:

1) Millaisia eri palveluita nuorten mielenterveyden tukemiseksi on Uudenmaan alueella?

2) Miten palvelut ja resurssit subteutuvat alueen väestöä kuvaavien tarveindikaattorien kanssa?

3) Onko Uudenmaan alueella lastensuojelun asiakkaana oleville lapsille tarjolla tasa-arvoisesti avohoidon mielenterveyspalveluita tai resursoitua henkilökuntaa?

Tutkimuksen hypoteesit liittyvät palveluyksikköjen ja -toimintojen tarkastelun lisäksi seuraaviin oletuksiin:

1) Palveluiden monipuolisuus ja tarjonta vaibtelevat kunnittain. Kuntien väkiluku ja hyvinvointiin vaikuttavat tekijät eroavat toisistaan. Kunnille ei ole myöskään olemassa selkeää, yhtenäistä ohjeistusta palveluiden järjestämiseksi, joten varsinkin varhaisen tuen järjestämisessä ne tekevät päätöksiä itsenäisesti.

2) Niillä alueilla, joissa sosiodemografiset mittarit osoittavat nuorten voinnista olevan buolenaihetta, on tarjolla monentasoisia mielenterveyspalveluita. Voisi olettaa, että kunnissa olisi haluttu reagoida esimerkiksi nuorten huonovointisuuteen, jolloin palveluntarjonta kasvaisi.

3) Kuntien henkilöstön resursointi avohoitopalveluibin ja monipuoliseen palveluntarjontaan perustuu väkilukuun, ja erityistä suojelua tarvitseville nuorille pyritään järjestämään varhaista tukea. Voi olettaa, että suurten väkimäärien kunnissa tai lastensuojelun asiakasmäärien kasvaessa kunnissa on pyritty panostamaan avohoidon ja varhaisen tuen resursointiin. 


\section{TUTKIMUSALUE}

Tutkimuksessa on selvitetty nuorten mielenterveyspalveluiden järjestämistä Uudenmaan 24 kunnan alueella vuonna 2014. Alue on Suomen väkirikkainta ja tiheämmin asuttua: yhteensä alueella asui 84068 nuorta. Suomessa on käynnissä laaja sosiaali- ja terveyspalveluiden uudistaminen, johon liittyy myös maakuntahallinnon perustaminen. Uusimaa on merkittävässä roolissa tulevassa uudistuksessa, koska se tulee muodostamaan asukasluvultaan selkeästi suurimman maakunnan. Iso väestöpohja ja kuntien erilaisiksi muodostuneet palvelurakenteet asettavat haasteita tasapuolisten palveluiden järjestämiselle. Tutkimusvuotena mielenterveyspalveluita oli tuotettu nuorille erikoissairaanhoidossa, kuntatasolla terveydenhuollossa, sosiaalipalveluissa ja koulussa sekä kolmannella sektorilla.

Helsinki, Espoo ja Vantaa ovat alueen isoimmat kaupungit, mutta alueella sijaitsee myös hyvin pieniä kuntia, joten palveluiden käyttäjämäärät vaihtelevat suuresti. Kuntien vaihtelevan koon vuoksi tutkimuksessa on mielekästä vertailla niiden lisäksi Uudenmaan eri sairaanhoitoalueita, jotka vastaavat erikoissairaanhoidon järjestämisestä ja huolehtivat siten terveydenhuollon vaativan tason ja erityisen vaativan tason palveluiden tuottamisesta. Sairaanhoitoalueita Uudellamaalla on viisi: HYKS-sairaanhoitoalue sekä Hyvinkään (HySHA), Lohjan (LoSHA), Länsi-Uudenmaan (LuSHA) ja Porvoon sairaanhoitoalueet (PoSHA). Tarkasteltaessa sairaanhoitoalueiden välisiä eroja on mielekästä erottaa Helsinki vielä erilleen muusta HYKS-alueesta. Pääkaupunkiasemansa ja kokonsa puolesta se eroaa muista alueen kunnista huomattavasti, mikä saattaa vaikuttaa myös palvelutarjontaan.

\section{AINEISTON KERUU JA ESMS-R MENETELMÄ}

Kaikki Uudenmaan alueen lapsille ja nuorille tarkoitetut mielenterveyspalvelut kartoitettiin ja toiminnot luokiteltiin vuosien 2013-2014 aikana osana Helsingin ja Uudenmaan sairaanhoitopiirin sekä Terveyden ja hyvinvoinnin laitoksen REFINEMENT (REsearch on FINancing systems' Effect on the quality of MENTal health care) -hanketta. Aineisto kerättiin julkisia tietolähteitä käyttäen sekä puhelin- ja kyselylomakeaineistolla kuntien ja yksityisten palveluntuottajien edustajilta. Kyselyllä selvitettiin yksikön toimintaa sekä henkilöstön resursointia. Palvelukartoituksen te- kemiseksi käytettiin lasten ja nuorten palveluihin sovellettua ESMS-R-työkalua (European Service Mapping Schedule, Revised, kuvio 1), joka on todettu aiemmissa tutkimuksissa toimivaksi tavaksi jäsentää olemassa olevia palveluntarjoajia (11, 17, 21). Aiemmin ESMS-työkalua on käytetty osana vastaavia aikuisille suunnattuja palvelunkartoituksia ja tutkimuksia yhdeksässä Euroopan maassa toteutettavaa REFINEMENT-hanketta varten. Hankkeessa tehdään vertailututkimusta erilaisista mielenterveysjärjestelmistä, niiden tuottamisesta ja kustannuksista. Tässä tutkimuksessa aineisto ja analyysi tehdään ensimmäistä kertaa nuorten palveluista.

Aineistoon kuuluvat kuntien ja kolmannen sektorin järjestämisvastuulla olevat nuorten mielenterveys- ja päihdepalvelut niin peruspalveluissa kuin erikoissairaanhoidon tasolla. Lisäksi mukana ovat lastensuojelun laitospalvelut sekä oppilashuollon ja päihdehuollon erityispalvelut. Sosiaalihuollon avopalveluiksi katsottiin kuuluvaksi aineistoa kerätessä muun muassa nuorisoasemat, kasvatus- ja perheneuvolat, etsivä nuorisotyö, perhetukikeskukset, jälkihuoltoa tarjoavat palvelut sekä perhekuntoutukset ja kotiin vietävä kriisityö. Järjestöjen ja yksityisten toimijoiden kunnille tuottamista palveluista kartoitettiin mielenterveys- ja päihdepalvelut. Lastensuojelun sijaishuollon palvelut otettiin mukaan kartoitukseen, mikäli merkittävä osa toiminnasta $(>20 \%)$ suuntautui nuoriin, joilla on mielenterveyden ongelmia. Lastensuojelun avohuollon palveluita ei REFINEMENT-hankkeessa kerätty.

ESMS-R-työkalulla (kuvio 1) ja siihen kuuluvalla luokittelulla mielenterveys- ja päihdepalveluiden katsotaan muodostuvan erilaisista toiminnoista, jotka sijoittuvat kartoitusmenetelmän kuuteen päätoimintoon. Jokainen olemassa oleva palvelutoiminto saa yhden pääkoodin sekä sitä tarkentavan alakoodin liittyen esimerkiksi palvelun akuuttiin luonteeseen tai lääkäripalveluiden saatavuuteen. Kaikkiaan nuorten aineistossa on mahdollista löytää 89 erilaista toimintomuotoa. (23.)

Neuvontapalveluiksi ovat luokiteltu sellaiset palvelut, joiden tehtävänä on tarjota tietoa mielenterveydestä ja olemassa olevista palveluista. Näihin ei sisälly seurantaa tai hoitoa. Aineistossa neuvontapalveluiksi on luokiteltu esimerkiksi ehkäisevän päihdetyön tarjonta nuorisotoimessa. 


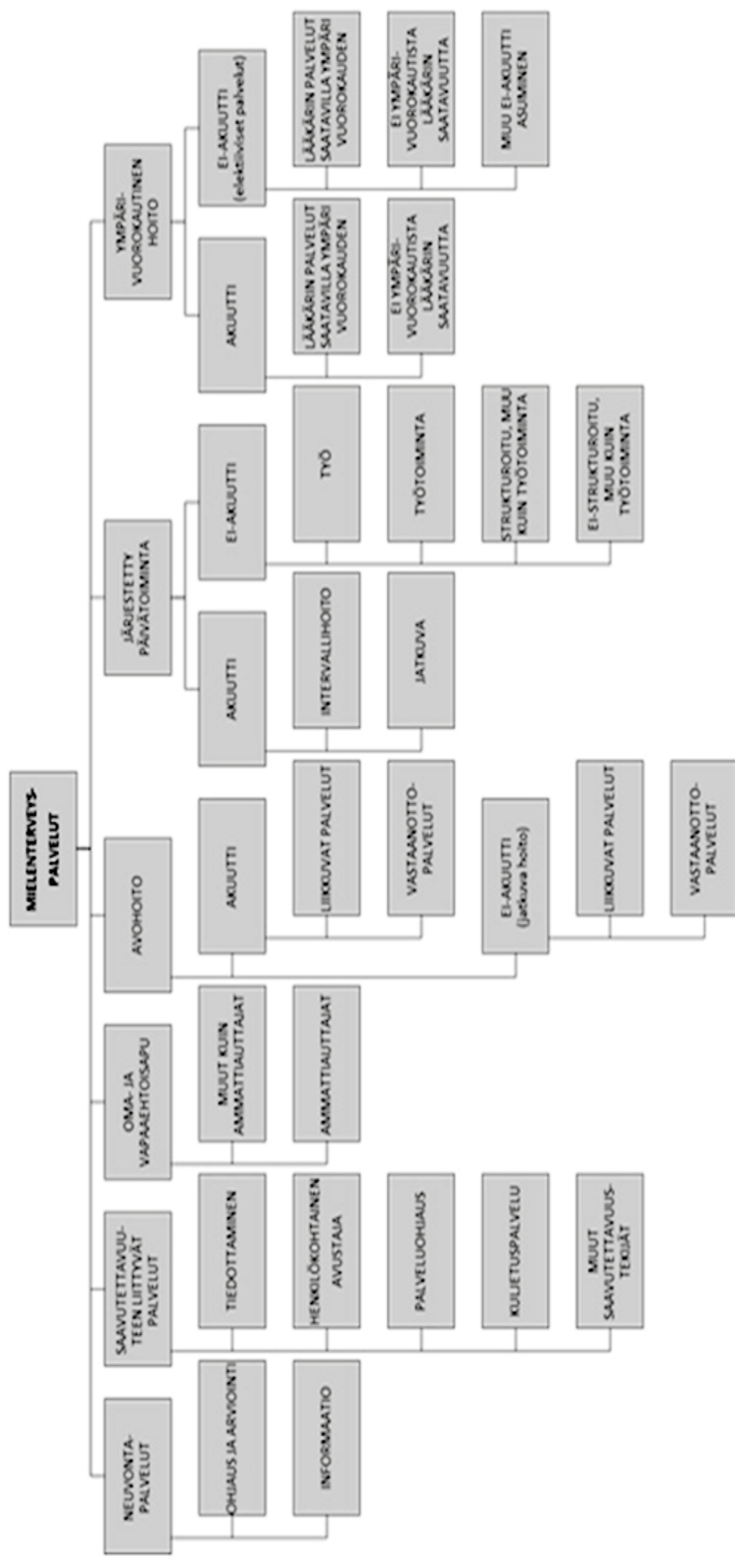

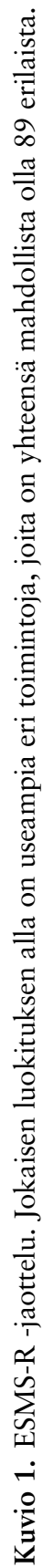


Saavutettavuuspalveluiden tarkoituksena on helpottaa mielenterveyshoitoon pääsyä, mutta ne eivät kuitenkaan itse tarjoa varsinaista hoitoa. Aineistossa saavutettavuuspalveluiksi koodattiin esimerkiksi etsivä nuorisotyö sekä muut nuorisotyön muodot, joissa on vahvana ajatus apua tarvitsevien nuorten löytämisessä ja ohjaamisessa mielenterveyspalveluihin.

Oma- ja vapaaehtoisapupalvelut kuvaavat palkattomien vapaaehtois- tai vertaisauttajien kanssakäymistä mielenterveyshoitoa tarvitsevien nuorten kanssa joko omana palvelunaan tai osana muuta hoitoa. Nuorten palveluissa tähän luokkaan kuuluvat muun muassa nuorten päihdehaittojen vertaisvalistusryhmät sekä eri järjestöjen tarjoamat vertaistukiryhmät, esimerkiksi syömishäiriöön tai autismin kirjoon liittyen.

Yhtenä isoimpana palveluluokkana ovat avohoidon palvelut. ESMS-R-luokittelulla avohoidolla tarkoitetaan tilanteita, joissa asiakas on mielenterveyden vuoksi yhteydessä ammattihenkilöön ilman, että se on osa ympärivuorokautista tai päivätoiminnan palvelua. Avohoidon mielenterveyspalveluiksi on luokiteltu muun muassa oppilashuolto ja kouluterveydenhoito, nuorisopsykiatria sekä muut mielenterveyspalveluihin kohdennetut säännölliset hoitokontaktit. Avohoito on luokittelussa jaettu vielä alahaaroihin esimerkiksi toiminnan akuutin luonteen (vastataan palveluntarpeeseen samana päivänä) ja palvelun liikkuvuuden (tarjotaanko palvelu hoitopaikassa vai kotona) perusteella. Lisäksi avohoito on luokiteltu vielä terveyteen liittyvään ja muuhun palveluun. Avohoidon palvelut on luokiteltu myös tapaamisten intensiteetin perusteella kolmeen eri luokkaan: matalan, keskitason ja korkean intensiteetin palveluihin. Korkean intensiteetin hoidossa tapaamisia on vähintään kolmesti viikossa, keskitason intensiteetillä tapaamisten on katsottu tapahtuvan vähintään kerran kahdessa viikossa ja matalan tason tapaamisia on harvemmin kuin kerran kahdessa viikossa.

Avohoidosta erillisenä on luokiteltu myös järjestetyn päivätoiminnan palvelut. Niihin luokitellut toiminnot tarjoavat yleensä ryhmämuotoista toimintaa nuorille yhdistäen mielenterveysongelmien hoidon ja sosiaalisen kanssakäymisen. Päivätoiminnat toimivat yleensä aukioloaikojen puitteissa ja tarjoavat toimintaa monen tunnin ajaksi: palvelut eivät perustu vain kahdenkes- kiseen tapaamiseen. Järjestetty päivätoiminta voidaan jakaa akuuttiin, suunniteltuun ja strukturoituun. Esimerkiksi nuorisopsykiatrian erikoissairaanhoidon tarjoamat intensiivihoidon jaksot sekä kuntien tarjoamat kuntouttavat työpajat ovat luokiteltu päivätoiminnoiksi.

Toinen hyvin keskeinen palveluluokka on ympärivuorokautiset palvelut, joissa hoitoa on tarjolla vuorokauden ympäri. Hoitoluokitukset on jaettu akuuttiin hoitoon, jossa palvelu järjestyy ympäri vuorokauden sairauteen liittyvän kriisin, fyysisen tai psyykkisen kunnon, käytöksen tai sosiaalisen toimintakyvyn heikentymisen takia. Tällaisia palveluita ovat esimerkiksi nuorisopsykiatrian akuuttiosastot. Lisäksi tarjolla voi olla myös rajattuja, suunnitelmallisia hoitojaksoja osastolla. Luokittelussa otetaan huomioon myös se, onko palvelussa tarjolla lääkärin palveluita ympäri vuorokauden vai rajoitetusti. Nuorten aineistossa lastensuojelulaitoksille on annettu myös kokonaan omat koodinsa, joiden perusteella voi tarkastella vielä toiminnan luonnetta: esimerkiksi nuorten päivystävät vastaanottokodit ja pitkäaikaista tukea tarjoavat nuorisokodit ovat aineistossa eroteltavissa.

\section{KÄYTETYT MUUTTUJAT}

Tutkimuksessa keskeisiksi kerätystä nuorten REFINEMENT-aineistosta on saatu palveluyksikköä, toiminnon tyyppiä sekä henkilöstöä koskevat muuttujat. Vakiintunut palveluyksikkö BSIC (basic stable inputs of care) on oma hallinnollinen yksikkönsä, joka tuottaa ja tarjoaa tietyn palvelun. Sille annetaan tarkentavia lisäkoodeja: palveluille määritellään pääasiallinen tarjottu toiminto MTC (main type of care) sekä sille vielä tarkennettu koodi liittyen esimerkiksi akuuttiin tai päivystykselliseen luonteeseen. Tutkimuksessa on tarkasteltu yksikköjä ja niiden pääasiallisia toimintoja. Lisäksi on tarkasteltu myös kunnasta löytyvää palvelutarjontaa, eli eri toimintotyyppien määrää.

Tutkimuksessa on käytetty sekä suoraan alueella olevaa henkilöstöresurssia että kunnittain jyvitettyä henkilöstöresurssia mitattuna henkilötyövuosina: tällä tavoin mahdollistui sekä henkilöstön sijainnin että alueellisen kohdentumisen mittaaminen kahden eri muuttujan avulla. Henkilöstöä mitattiin eri ammattiryhmittäin, ja henkilöstön käyttö jyvitettiin yksiköistä saadun tiedon perusteella tutkimusalueen kunnille. 
Nuorten hyvinvointiin ei ole saatavilla tai tarpeellistakaan saada täysin vastaavia mittareita kuin aikuisilla, mutta tutkimukseen valikoitui tausta- ja vastemuuttujiksi aiempien tutkimusten perusteella todennettuja nuorten mielenterveyteen vaikuttavia tekijöitä $(1-2,22)$.

Eri alueiden nuorten tilannetta on kuvattu käyttämällä nuorten keskiväkilukua, toimeentulotukea saaneiden perheiden määrää, aikuisten mielenterveysindeksiä, tehtyjen lastensuojeluilmoitusten määrää nuoruusikäisten kohdalla ja nuorten määrää lastensuojelun asiakkaina. Lisäksi on tarkasteltu nuorisopsykiatrian sairaanhoitopäiviä. Muuttujat on kerätty Terveyden ja hyvinvoinnin laitoksen (THL) SOTKAnetistä sekä erikseen pyydetty tutkimuskäyttöön nuorten lastensuojelutietoa THL:stä. Tässä tutkimuksessa haluttiin tarkastella nimenomaan nuorten tilannetta, joten tarkat luvut 13-17-vuotiaiden nuorten lastensuojeluasiakkuuksista on saatu pyytämällä ne eriteltynä ikäryhmittäin jokaisen kunnan osalta.

Nuorille ei ole olemassa omaa mielenterveysindeksiä, joten tutkimuksessa tarkastellaan palveluiden suhdetta aikuisten vuoden 2012 mielenterveysindeksiin. Mielenterveysindeksi perustuu tietoihin kunnassa tapahtuneista itsemurhista ja niiden yrityksistä, psykoosilääkkeiden erityiskorvaukseen oikeutettujen määrästä sekä mielenterveysperusteisten työkyvyttömyyseläkkeiden määrästä. Luku 100 vastaa koko maan tasoa, ja sitä korkeampi luku kunnan kohdalla heijastaa mahdollisesti suurempaa tarvetta mielenterveyspalveluille. Aiemmissa tutkimuksissa $(1,2,5)$ on havaittu vanhempien mielenterveysongelmien vaikuttavan vahvasti lasten ja nuorten mahdolliseen sairastuvuuteen ja sen riskitekijöihin.

Pitkään jatkunut taloudellinen niukkuus on yhteydessä nuorten mielenterveysongelmiin ja lastensuojelun asiakkuuteen sekä kodin ulkopuolisiin sijoituksiin $(5,18)$. Tässä tutkimuksessa onkin käytetty kunnan toimeentulotukea saaneiden lapsiperheiden osuutta kuvaamaan tässä riskissä elävien nuorten osuutta kunnassa.

Tehtyjen lastensuojeluilmoitusten ja lastensuojelun avohuollon asiakkaiden määrät kuvaavat tutkimuksessa nuorten yleistä hyvinvointia alueella. Nuoruusikäisistä tehdyistä lastensuojeluilmoituksista suurin osa liittyy nuorten omaan käyttäytymiseen ja sen riskeihin. Myös lastensuojelun asiakaslapsilla on usein psyykkisiä vai- keuksia ja mielenterveysongelmia, jotka vaativat vähintään arviointia tai hoitoa. (4, 6, 24). Korjaaviksi ja viimesijaisiksi palveluiksi määritellään tutkimuksessa erityisen vaativan tason palvelut: lastensuojelun 13-17-vuotiaiden kodin ulkopuolelle tehtyjen sijoitusten määrällä sekä nuorten psykiatristen hoitojaksojen lukumäärällä kuvataan näiden palveluiden tarvetta tai käyttöä alueella.

\section{AINEISTON ANALYYSI}

Tutkimuksen aluksi lasten ja nuorten palveluista koottu REFINEMENT-aineisto käsiteltiin tutkimuskysymyksiin soveltuvaksi. Aineistosta poistettiin kaikki lapsille ja aikuisille suunnatut palvelut ja huomioitiin ainoastaan ne muuttujat, jotka on suunnattu lapsille ja nuorille yhdessä, pelkästään nuorille sekä nuorille ja aikuisille: tällä tavoin on saatu rajattua palvelut niihin, joita 13-17-vuotiaat voivat tosiasiallisesti käyttää. Aineistosta on myös poistettu palvelut, jotka sijaitsevat muualla kuin Uudenmaan alueella. Näitä yksiköitä oli 24 kappaletta, ja ne ovat pääasiassa yksityisiä lastensuojelun sijoituspaikkoja: ne eivät ole suoraan kuntalaisten käytettävissä, ja palvelut niistä ostetaan vain erityisissä lastensuojelutapauksissa kunnan koordinoimana.

Aineisto käsiteltiin IBM SPSS 23.0 -ohjelmalla. Analyysissä huomioitiin aineiston suhteellisen pieni koko ja aiemmissa tutkimuksissa REFINEMENT-aineiston käsittelyyn toimivaksi havaitut menetelmät $(21,25)$. Osittain samojen menetelmien käyttö mahdollistaa nuorten ja aikuisten palvelun vertailun.

Alueen kokonaishenkilöstön resursointi saatiin laskemalla jyvitettyjen henkilötyövuosien (htv) yhteenlaskettu määrä nuorten palveluissa. Kunta- ja aluekohtaisesti on huomioitu kaikki palvelut, jotka sijaitsevat Uudenmaan alueella ja palvelevat kyseisen kunnan nuoria. Saatu henkilötyövuosien kokonaisjyvitys alueittain jaettiin koskemaan tuhatta alueella asuvaa nuorta. Avohoidon henkilöstö laskettiin poistamalla asumispalveluihin (sijaishuoltoon ja psykiatrian laitospaikkoihin) kohdennettu henkilöstö. Luku jaettiin tämä määrä koskemaan tuhatta alueen 13-17-vuotiasta. Avohoitopainotteisuus selvitettiin laskemalla avohoidon palveluihin ja päivätoimintoihin resursoitu henkilöstö ja jaettiin tämä luku asumispalveluihin resursoiduilla henkilötyövuosilla. Oma-apu ja vapaaehtoispalve- 
lut sekä saavutettavuuspalvelut jätettiin pois, sillä niissä ei ole resursoituja henkilötyövuosia. Avohoitopainotteisuudella kuvataan sitä, minkä verran alueet ja kunnat ovat painottaneet avopalveluita suhteessa viimesijaisiin ja korjaaviin palveluihin.

Sosiodemografisten muuttujien ja hyvinvointi-indikaattorien suhdetta palveluihin tarkasteltiin Spearmanin kaksisuuntaisella korrelaatiolla (jossa p:n arvoa alle 0,05 on pidetty tilastollisesti merkitsevänä). Eri toimintoyksikköjen ja toimintotyyppien määrän, avohoidon kokonaisresurssien ja avohoitopainotteisuuden suhdetta tutkittiin valikoitujen taustamuuttujien kanssa. Yhteyttä ja selitystä avohoidon ja psyykkisen hyvinvoinnin riskitekijöiden välillä kuvataan sirontakuviolla, jossa yksi piste vastaa yhtä kuntaa. Kuviin on piirretty Loessin ei-parametrinen käyrä havainnollistamaan selitysastetta. (26.)

\section{TULOKSET}

\section{NUORILLE SUUNNATUT MIELENTERVEYSPALVELUT VUONNA 2014}

ESMS-R-jaottelulla tarkasteltuna Uudenmaan nuorten mielenterveyspalveluita hallitsivat lastensuojelulaitokset ja terveydenhuollon matalan intensiteetin avohoito (taulukko 1). Ympärivuorokautiset, akuutit sairaalaosastot olivat tarkasteluajankohtana keskittyneet HYKSin alueelle Helsinkiin ja Hyvinkään alueelle. Helsingin lisäksi ainoastaan Länsi-Uudenmaan ja Hyvinkään alueet tarjosivat ei-akuutin hoidon osastot. Kaikista mielenterveystoiminnoista ylivoimaisesti eniten oli lastensuojelulaitoksia, ja toisin kuin sairaalaosastot, ne olivat keskittyneet Helsingin lähikuntiin.

Korkean intensiteetin avohoito puuttui $\mathrm{Uu}^{-}$ denmaan nuorten palveluvalikosta kokonaan, ja myös keskitason intensiteetin hoitoa oli tarjolla vaihtelevasti. Keskitason intensiteetin palveluita oli tarjolla Hyvinkään alueella neljässä yksikössä, Lohjalla yhdessä ja Porvoon alueella kahdessa yksikössä, mutta muilla alueilla näitä ei ollut lainkaan. Liikkuvaa avohoitoa oli valikossa isoimmilla alueilla, mutta niiden tarjonta vaikutti olleen varsin vaihtelevaa. Liikkuvia avotoimintoja tarjoavia yksiköitä oli eniten muun HYKSin alueella (14), ja sen jälkeen Hyvinkään alueella (8). Avohoitotoiminnoissa oli eniten tarjolla matalan intensiteetin avohoitoa, joka ESMS-R-luo- kittelulla tarkoittaa tapaamisia harvemmin kuin kerran kahdessa viikossa.

Myös päivätoimintojen määrä vaikuttaa satunnaiselle. Oma-apu-toiminnot keskittyivät suurten väkimäärien paikkoihin siten, ettei Porvoon ja Länsi-Uudenmaan alueella ollut näitä lainkaan. Neuvontatoimintoja tarjoavia yksiköitä löytyi yksi Helsingistä ja toinen Lohjan alueelta.

\section{PALVELUIDEN SUHDE NUORTEN PSYYKKISEEN HYVINVOINTIIN VUONNA 2014}

Nuorten määrä suhteessa muuhun väestöön oli suurempi Uudenmaan kehyskunnissa kuin pääkaupunkialueella. Esimerkiksi Hyvinkään alueella nuoria oli 6,6 \% koko väestöstä, Helsingissä osuuden ollessa vain 4,2. Pääkaupunkiseudun nuorilla näytti olevan kuitenkin alueen väkilukuun suhteutettuna eniten psyykkiseen hyvinvointiin vaikuttavia riskitekijöitä. Helsinki erottui hieman myös muusta HYKS-alueesta haasteiden kasautumisen suhteen. Toimeentulotukea saaneiden lapsiperheiden osuus kaikista lapsiperheistä oli lähes 4 prosenttiyksikköä Uudenmaan aluetta korkeampi (taulukko 2). Vaikka aikuisten mielenterveysindeksi oli Uudenmaan alueella selkeästi koko Suomen tasoa matalampi (Uudenmaan alueella 76,7, koko Suomen 100), oli Helsinki muita alueita hieman korkeammalla $(80,0)$ kun taas muu HYKS-alue $(74,9)$ sijoittui lähemmäs Uudenmaan keskitasoa.

Tehtyjä lastensuojeluilmoituksia (11,1\%) ja avohuollon asiakkaina olevia $(11,2 \%)$ oli väkilukuun suhteutettuna Helsingissä ja muun HYKSin alueella $(9,4 \%$ ja $11,1 \%)$ enemmän kuin muualla Uudenmaan alueella. Sen sijaan kodin ulkopuolelle sijoitettujen nuorten osuus väkiluvusta oli Helsingissä selkeästi korkeampi $(3,9 \%)$ kuin muulla HYKS-alueella $(2,7 \%)$. Sijoitettujen nuorten osuus väkiluvusta näyttää pienenevän alueen väkimäärän mukaan.

Nuorisopsykiatrian palveluiden tai mielenterveyden avohoitoresurssien käytössä pääkaupunkiseutu ei kuitenkaan ollut Uudenmaan alueen korkeimmalla tasolla. Taulukon 2 perusteella on huomattavissa, että riskitekijät kasautuivat pääkaupunkiin ja palveluiden monipuolisuus oli alueella laajaa (toimintotyyppien määrä Helsingissä on 29), mutta avopalveluiden käyttö tuhatta nuorta kohden $(1214,5)$ ei ollut kuitenkaan suurinta. Erityisesti nuorisopsykiatrian avohoidon hoitokäyntejä näytti olevan eniten 


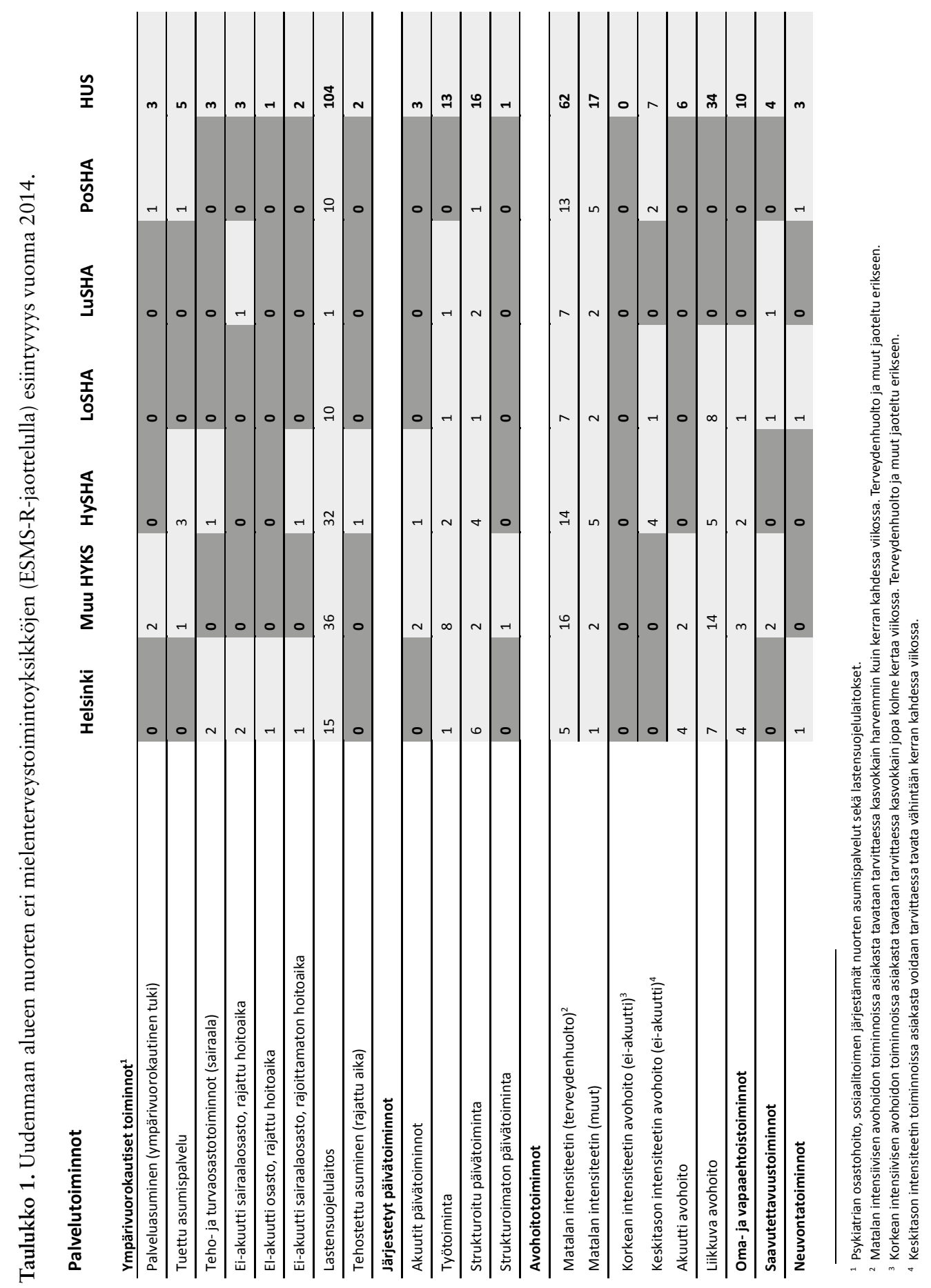




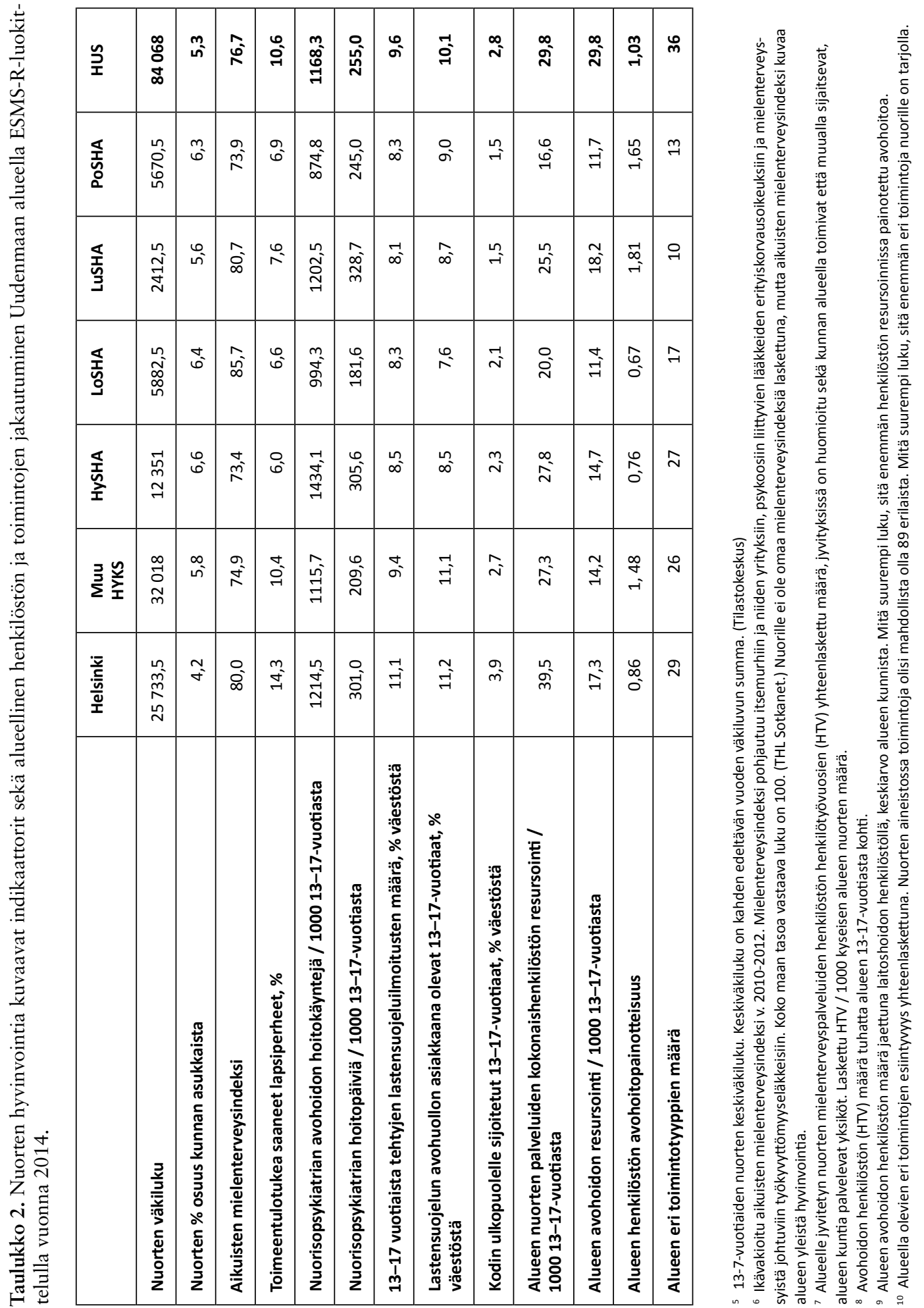


Hyvinkään sairaanhoitoalueella $(1434,1)$, mikä ei kuitenkaan näyttänyt vähentävän vuodeosaston käyttöä: osastohoidon hoitopäiviä tuhatta nuorta kohden oli alueella toisiksi eniten $(305,6)$. Alueen muut indikaattorit eivät osoittaneet tälle selitystä erityisen korkeilla luvuilla.

Lohjan alueella, jossa mielenterveysindeksi oli koko Uudenmaan korkein $(85,7)$, oli nuorisopsykiatrian hoitopäiviä koko sairaanhoitopiirin vähiten $(181,6)$. Myös alueen avohoidon henkilöstöresurssit olivat koko Uudenmaan pienimmät (11,4 htv /1000 nuorta), ja alueen avohoitopainotus myös pienintä $(0,67)$. Samoin Lohjan alueen avohuollon lastensuojeluasiakkaiden määrä vastaavan ikäisistä oli koko Uudenmaan pienintä $(7,6 \%)$, vaikka lastensuojeluilmoituksia tehtiin lähes saman verran kuin muilla alueilla.

Länsi-Uudenmaan henkilöstön resursoinnissa oli painotettu eniten avohoitoa (avohoitopainotteisuusluku 1,81), ja alueella oli toiseksi eniten (18,2 / 1000 nuorta) avohoitoon resursoitua henkilöstöä. Toisaalta siellä myös nuorisopsykiatrian osastohoitopäiviä oli koko Uudenmaan alueella eniten $(328,7)$. Länsi-Uudenmaan lastensuojeluasiakkaiden tai -ilmoitusten määrät eivät olleet erityisen korkeita; sen sijaan seudun mielenterveysindeksi oli koko Uudenmaan alueen toisiksi korkein $(80,7)$.

Porvoon alueella aikuisten mielenterveysindeksi oli koko sairaanhoitopiirin alhaisin $(73,9)$. Avohoidon painotus oli toisiksi suurinta: verrattuna lähes samankokoiseen Lohjan alueeseen Porvoon avohoidon painotusluku $(1,65)$ oli yli kaksinkertainen. Lastensuojelun avohuollon asiakkaita sekä nuorisopsykiatrian osastohoitopäiviä Porvoossa oli puolestaan Lohjan aluetta enemmän.

\section{AVOHOIDON RESURSSEJA TARJOLLA SATUNNAISESTI}

Mielenterveyspalveluiden tarjonta ja suhde taustamuuttujiin näyttää vaihtelevalta (taulukko 3). Nuorten määrä kunnassa korreloi voimakkaasti niin sosiodemografisten muuttujien kuin toimintoyksikköjen ja -toimintotyyppien määrän suhteen ( $\mathrm{r}=0,835-0,750$ merkitsevyystasolla $\mathrm{p}<0,001)$. Näyttää siltä, että kunnan koon kasvaessa erilaiset hyvinvoinnin haasteet kasvoivat, mutta myös toimintoyksikköjen ja toimintotyyppien määrä nousi samassa suhteessa. Tausta- muuttujat korreloivat hyvin vahvasti keskenään, ja hyvinvoinnin riskitekijät olivat mielenterveysindeksiä lukuun ottamatta vahvasti yhteydessä toisiinsa. Aikuisten mielenterveyttä heijasteleva indeksi ei ollut yhteydessä mihinkään asetettuun muuttujaan merkitsevästi ( $\mathrm{p}<0,001$ tai $\mathrm{p}<0,005)$.

Palveluntuottajia näytti olevan eniten siellä missä nuoriakin. Esimerkiksi toimintoyksiköiden määrä HUS-alueella korreloi väkiluvun $(\mathrm{r}=0,835)$ ja toimeentulotukiasiakkaiden $(\mathrm{r}=0,864)$ sekä tehtyjen lastensuojeluilmoitusten $(r=0,914)$ määrien kanssa vahvasti. Sen sijaan henkilöstön resursointi avohoitoon ja kunnan alueen painotus avohoidon henkilöstöön ei ollut tässä tutkimuksessa tilastollisesti merkittävästi yhteydessä minkään oletetun palvelutarvetta kuvaavan muuttujan kanssa.

Kuviossa 2 (a-c) on havainnollistettu avotoimintojen ja resurssien tarjontaa kunnittain. Kuvioihin on piirretty Loessin käyrä kuvaamaan selityksen astetta. Sekä kunnassa asuvien nuorten että lastensuojelun asiakkuuksien määrän kasvaessa myös erilaiset avotoiminnot lisääntyivät. Avo-, päivä-, neuvonta-, saavutettavuus- ja vertaistoimintojen määrä näytti selittyvän sekä alueen nuorten väkiluvulla että lastensuojelun avohuollon asiakkaiden sekä sijoitettujen nuorten määrällä (kuvio 1). Uudenmaan alueen suuret kunnat (Helsinki, Espoo ja Vantaa) erottuivat sekä toimintojen tarjonnan että lastensuojelun asiakasmäärien suhteen muista kunnista.

Avohoidon resursointi tai avohoitopainotus kunnassa eivät selittyneet nuorten väkiluvulla, lastensuojelun avohuollon asiakkaiden määrällä tai kodin ulkopuolelle sijoitettujen nuorten määrällä. Erot eivät muutu merkittävästi, vaikka väkiluvultaan eroavat isot kunnat poistettaisiin tarkastelusta. Avohoidon resursointi vaikuttaa olevan tämän tarkastelun perusteella satunnaista, eikä se selity kunnan nuorten mahdollisella tarpeella. Kodin ulkopuolelle sijoitettujen nuorten määrä kunnassa voi olla hyvin suuri tai pieni, mutta avohuollon henkilöstön määrä suhteessa tuhanteen 13-17-vuotiaaseen ei selittynyt sen perusteella (kuvio 2b). Avohoidon painotus kunnassa vaikutti olevan sattumanvaraista (kuvio 2c), eikä se selittynyt väkiluvulla tai lastensuojelun asiakasmäärillä. 

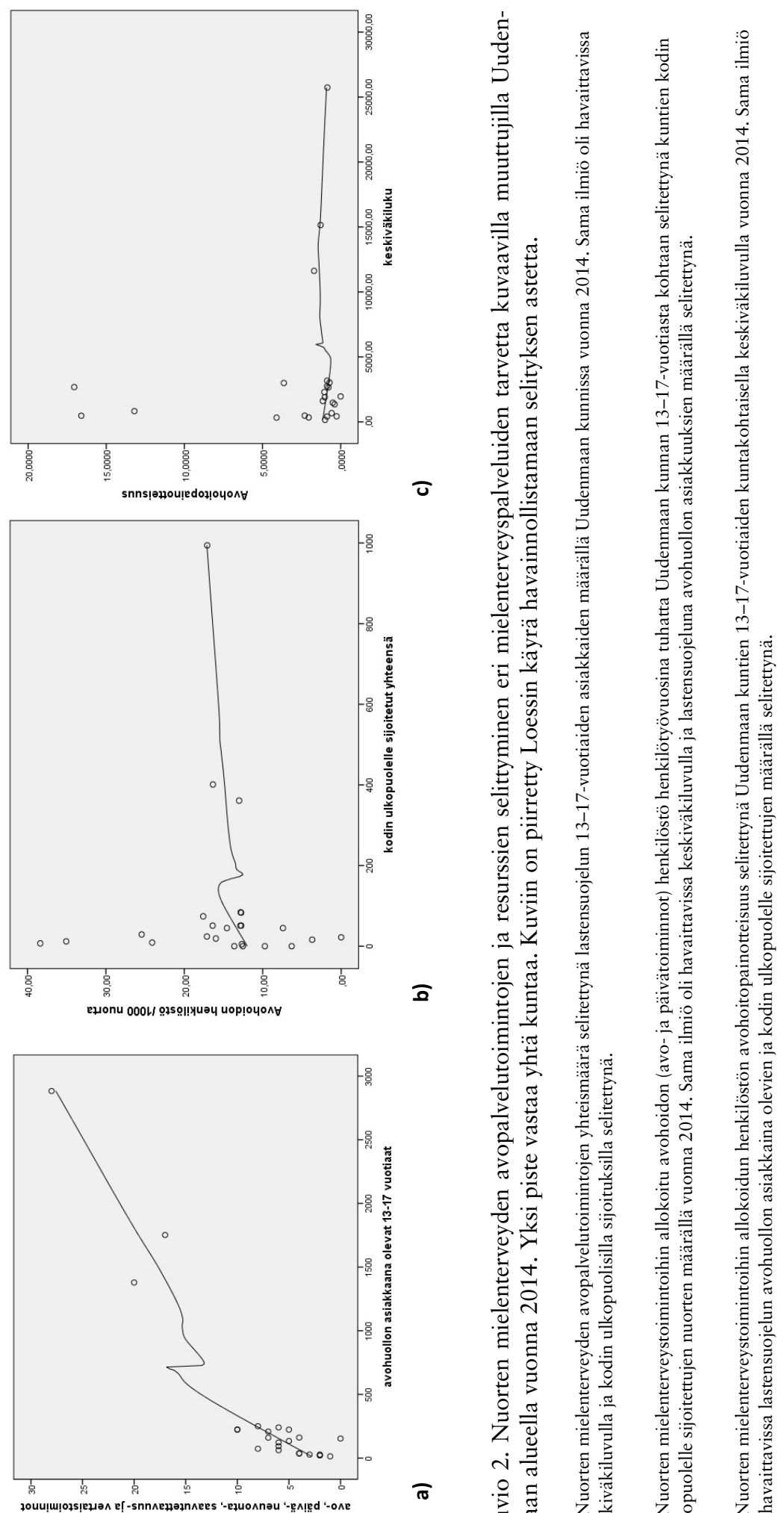

กั
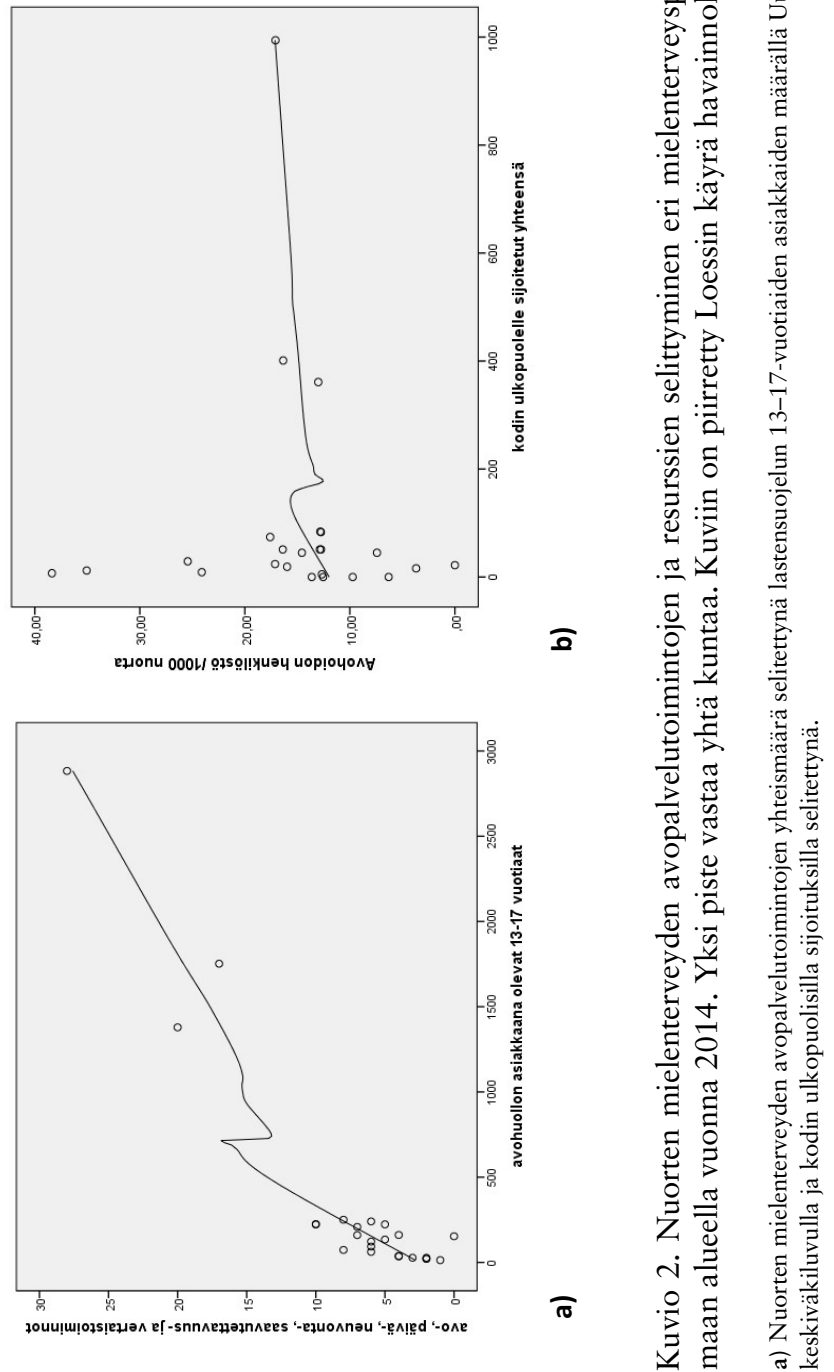

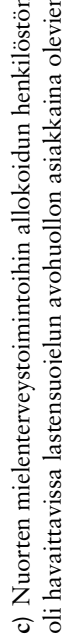




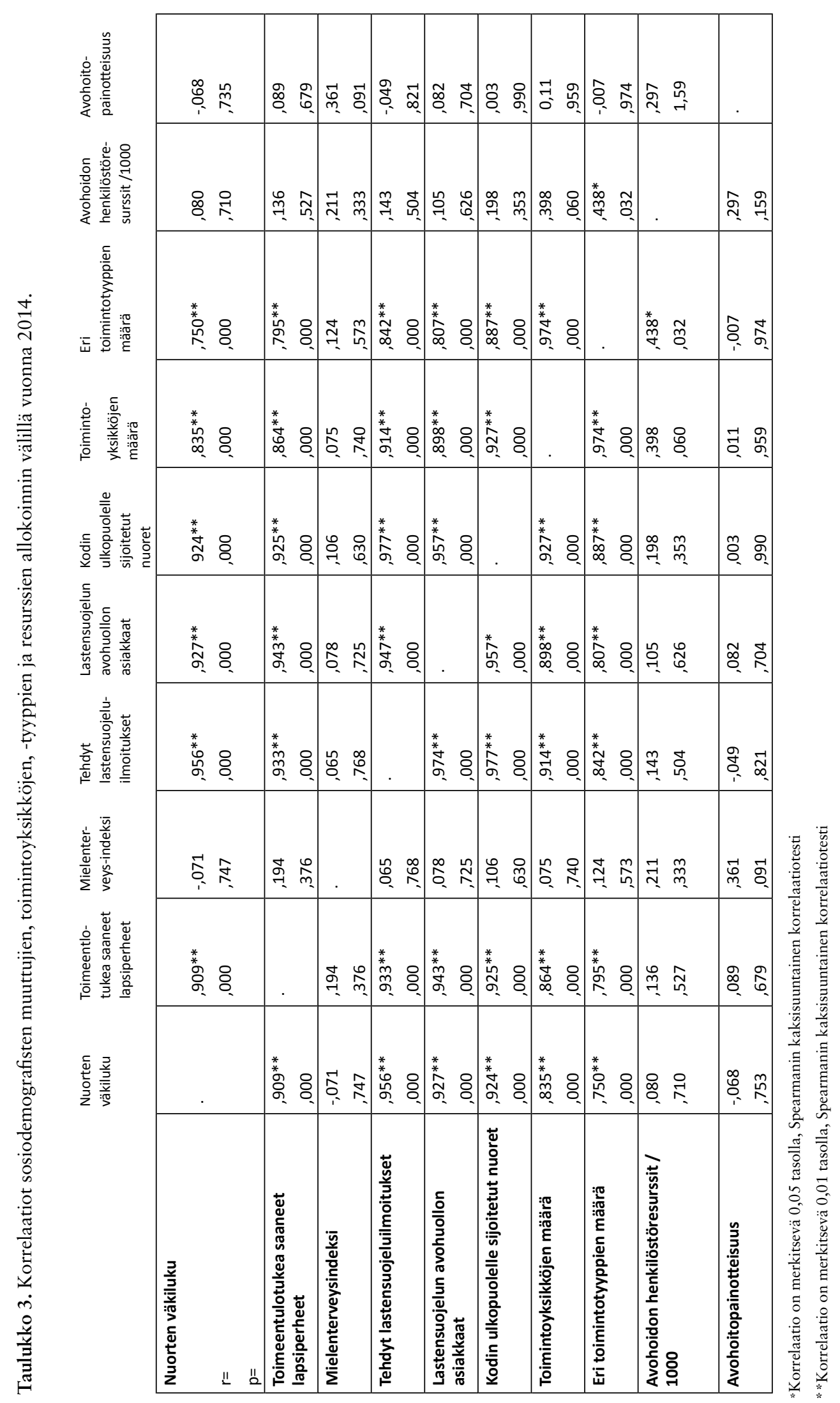




\section{POHDINTA}

Tutkimuksen tulosten perusteella näyttää siltä, että nuorten hyvinvoinnin riskitekijät kasautuivat pääkaupunkiin. Samoin myös erilaisten palveluiden tarjonta kohdentui pitkälti sinne, missä nuoria on väkimäärältään eniten. Kuten ensimmäisessä hypoteesissa oletettiin, palveluiden tarjonta ja monipuolisuus vaihtelivat kunnittain - selittävänä tekijänä tälle vaihtelulle näytti olevan pitkälti kunnan asukkaiden määrä. Isojen kaupunkien palvelutarjonta oli huomattavasti muita alueita suurempi, ja erityisesti sairaalahoito oli keskitettyä. Monilta alueilta puuttuivat kokonaan esimerkiksi päivätoimintojen ja liikkuvan avohoidon palvelut, eikä nuorille ei näyttänyt olevan kaikilla alueilla lainkaan mahdollisuutta matalan kynnyksen neuvontatoimintoihin pääsyyn. Aiempien tutkimustulosten perusteella nuorille on suositeltu ennaltaehkäisevien lähipalveluiden järjestämistä. Tutkimuksissa on tunnistettu niitä tekijöitä, jotka altistavat nuoret mielenterveyden häiriöille. Varhaisen tuen vaikutus myöhempään hyvinvointiin ja yhteiskuntaan kiinnittymiseen on myös havaittu. (1-2, 5-6, 8-9.) Esimerkiksi akuutti avohoito voisi ehkäistä osastohoidon tarvetta (9), mutta toimintona sitä ei ollut saatavilla muualla kuin Helsingin ja HYKSin alueella.

Tutkimuksen toinen hypoteesi perustui ajatukseen, että kunnat ovat reagoineet nuorten mahdolliseen palveluntarpeeseen. Ajatuksena oli, että niillä sairaanhoitoalueilla, joissa sosiodemografiset mittarit osoittavat nuorten voinnista olevan huolta, on tarjolla erityisen monimuotoisia mielenterveyspalveluita. Tulosten perusteella näyttää siltä, että palveluntarjoajia on eniten siellä, missä nuoria on paljon. Isommilla alueilla tarjonta myös viimesijaisista palveluista kasvaa. Vaihtoehtoisesti voi myös ajatella, että palveluita hyödynnetään myös eniten silloin, kun ne ovat läheisesti saatavilla.

Aiempien tutkimustulosten $(1,4-6)$ valossa oletettiin, että kunnissa olisi huomioitu lastensuojelun asiakkaana olevien nuorten tarpeet ja kohdennettu resursseja mielenterveyden avopalveluihin. Tämä kolmas tutkimushypoteesi kumoutui tulosten perusteella. Aineiston ja analyysin perusteella vaikuttaa, että erilaisten avopalvelutoimintojen määrä oli yhteydessä väkilukuun sekä lastensuojelun avohuollon asiakkaiden ja sijoitettujen nuorten määrään. Yllättäen avohoidon painotus resursoinnissa tai avohoidon henkilöstö tuhatta nuorta kohden olivat kuitenkin satunnaisia. Tulosten perusteella on oletettavaa, etteivät kunnat tai alueet painota avohoidon resursseja silloin, kun kunnassa on paljon nuoria tai mikäli niille saattaisi olla tarvetta esimerkiksi lastensuojelun asiakasmäärien kasvaessa. Lastensuojelun asiakkaina olevien nuorten mielenterveyden pulmia ja hyvinvointia on tutkittu paljon, mutta nähtävästi henkilöstön kohdentamisessa tätä ei ole huomioitu. Tulokset vahvistivat lastensuojelussa olevaa kokemustietoa (7) siitä, ettei asiakkaille ole tarjolla riittävästi mielenterveyden hoitoon kohdennettuja resursseja.

Kansainvälisissä tutkimuksissa on korostettu huomion kiinnittämistä siirtymävaiheisiin. Siirto lasten ja nuorten palveluista aikuisille suunnattuihin palveluihin on haasteellista erityisesti kodin ulkopuolelle sijoitettujen nuorten kohdalla $(4,24)$. Nämä nuoret ovat vaarassa jäädä yhteiskunnan ulkopuolelle, mikäli he eivät saa tarvitsemiaan palveluita (27). Aikuisten palveluita tarkastellessa ESMS-R-luokittelulla on havaittavissa vastaavanlaista sattumanvaraisuutta kuin nuorilla palveluiden tarjonnassa (21). Tämä herättää pohtimaan, mitä tapahtuu nuoren tullessa täysi-ikäiseksi? Jatkossa olisi mielekästä tutkia tätä rajapintaa palveluiden tarjonnassa kuntatai aluekohtaisesti.

Saadut tulokset perustuvat ESMS-R-menetelmän luokituksiin. Vaikka mittari on useissa tutkimuksissa todettu hyväksi tavaksi standardoida ja mitata palveluiden tarjontaa, on sillä myös omat rajoitteensa. Toimintojen määrästä ei voi suoraan tehdä päätelmiä järjestelmän kannattavuudesta tai toiminnoista. Suuri samanlaisten toimintojen lukumäärä saattaa kertoa valinnanvarasta, mutta myös palvelujärjestelmän hajanaisuudesta. Isommissa kaupungeissa voi olla enemmän pahoinvointia, tai vaihtoehtoisesti suuremman palveluvalikon kunnissa pahoinvointi tulee todennäköisemmin esiin ja tutkijoiden analysoitavaksi. Kaupungeissa palveluiden keskittäminen on usein suotavaa, mikä näkyy pienempänä toimintomääränä asukasta kohti. Myöskään suuri sairaalaosastojen määrä ei kerro välttämättä laadukkaasta palveluntarjonnasta. (17.) Mikäli palveluiden laadusta tai nuorten omista kokemuksista palvelujärjestelmän toimivuudesta haluttaisiin tutkimustuloksia, tulisi asetelma toteuttaa nuorilta itseltään kysyen. 
Tulokset kertovat vain yhden maakunnan tilanteesta. Vastaavan tutkimuksen toteuttaminen muidenkin maakuntien alueella voisi antaa vielä selkeämmän kuvan koko Suomen nuorten palvelutarjonnasta. Uudenmaan suuri väestöpohja ja esimerkiksi järjestöjen keskittyminen pääkaupungin alueelle vaikuttavat todennäköisesti tuloksiin. Muiden maakuntien tilannetta tarkastelemalla olisi mahdollista tehdä myös alueellista vertailua.

Tämän tutkimuksen tulokset antavat kuitenkin selkeitä suuntaviivoja siitä, että henkilöstöresurssit ovat jakautuneet Uudenmaan alueella epätasaisesti. Palvelut on kartoitettu systemaattisesti ja luotettavaa menetelmää käyttäen. Kartoituksessa tietoja on hankittu useasta eri lähteestä ja tarkennettu mahdollisia epäselviä kohtia mahdollisimman kattavan tiedon saamiseksi. Tässä tutkimuksessa on ensimmäistä kertaa tarkasteltu laajalla, systemaattisesti kerätyllä aineistolla nuorten mielenterveyspalveluiden järjestämistä maakunnan alueella. Tutkimuksen tuloksissa kuvataan palveluiden ja henkilöstöresurssien epätasaista jakautumista alueiden ja kuntien välillä. Vastaavaa kartoitusta tai havainnollistusta nuorten mielenterveyspalveluista ei ole Suomessa aiemmin tehty, joten jatkossa seurantatutkimuksilla voisi tarkastella muuttuisivatko tulokset esimerkiksi sosiaali- ja terveydenhuoltouudistuksen jälkeen.

\section{JOHTOPÄÄTÖKSET}

Tutkimuksen perusteella näyttää siltä, että Uudenmaan alueen nuorten palveluntarjonta jakautui vaihtelevasti ja oli osin puutteellista. Kuntien ja alueiden avopalveluiden resursointi tai painottaminen ei kohdistu sinne, missä nuoria tai erityisen suojelun tarpeessa olevia nuoria oli paljon. Päätöksiä on tähän asti tehty sekä kuntatasolla peruspalveluissa että erikoissairaanhoidon osalta alueittain. Erityisesti matalan kynnyksen avopalvelut ovat olleet riippuvaisia kuntien tekemistä poliittisista ratkaisuista ja resurssipäätöksistä. Käynnissä oleva sosiaali- ja terveydenhuoltouudistus tarjoaisi nyt mahdollisesti tuleville maa- kunnille mahdollisuuden koordinoida palvelut tarpeen mukaan ja tutkimustietoon perustuen.

Tämä tutkimus tuo uutta tietoa kunta- ja maakuntapäättäjien tiedonmuodostuksen tueksi, ja tällä havainnollistetaan eroja jo yhden maakunnan sisällä. Tutkimuksen tulokset ovatkin tarpeen suunniteltaessa palveluiden kehittämistä siten, että kaikilla nuorilla on kotikunnasta riippumatta tarjolla yhtäläisiä palveluita yhteiskuntaan kiinnittymisensä tueksi. Erityisesti matalan kynnyksen avohoitopalveluiden järjestämiseen ja avohoidon resursointiin tulisi kiinnittää tulevien palveluiden suunnittelussa huomiota.

Jatkossa olisi tärkeää tutkia myös henkilöstön koulutusta ja osaamista. Saavatko nuoret psykiatriseen osaamiseen perustuvaa apua muualtakin kuin varsinaisista mielenterveyspalveluista? Erityisesti lastensuojelulaitoksiin on sijoitettu paljon mielenterveysongelmista kärsiviä nuoria. Laitoksissa voi olla myös paljon sisäänrakennettuna osaamista tarvittavan tuen suhteen. Sosiaali- ja terveyspalveluiden uudistukseen kuuluvaan valinnanvapauteen liittyen olisi tärkeää tarkastella maakuntatasoisesti myös osaamisen, ei vain palveluiden jakautumista.

On huomioitava, etteivät monen eri toimijan palvelut aina tuo parhaita tuloksia ongelmien hoidossa tai ennaltaehkäisyssä, mutta resurssit vaikuttavat siihen, miten paljon työntekijöitä nuoria on kohtaamassa. Varhaisen tuen palveluiden merkitys myöhemmälle hyvinvoinnille on keskeistä. Resurssien tarpeenmukaisella kohdentamisella voitaisiin vaikuttaa siihen, ettei 87-kohortin kaltaisia tutkimustuloksia nuorten hyvinvoinnista enää tulisi.

\section{KIRJOITTAJIEN KONTRIBUUTIOT:}

Hedman on muotoillut tutkimuskysymykset, käsitellyt datan tutkimukseen soveltuvaksi ja analysoinut tulokset sekä kirjoittanut käsikirjoituksen. Vastamäki on kerännyt REFINEMENT-aineiston ja osallistunut käsikirjoituksen kommentointiin. Joffe on osallistunut analysoinnin ja käsikirjoituksen kommentointiin. 
In recent discussion there has been concern over mental health issues of adolescents, especially among customers of child welfare. Mental health services should have their focus on early interventions and basis as out-patient care near home. The on-going national reform of social and health care requires also empirical data of services at all levels. The aim of this study was to describe mental health services for adolescents in the Uusimaa region in the year 2014. All services were mapped with an adolescent-compatible modification of the ESMS-R. Services were explored by quantity and diversity, personnel resources of out-patient care and child welfare customers' access to using mental health services. Risk factors and diversity of mental health services correlated with the size of the municipality. Personnel resources in out-patient care or outpatient-ratio did not associate with population or child welfare customers. There was also a shortage of day care and home-based services. The differences in personnel resources and their out-patient ratios mean that the service users are in unequal positions. This might be a consequence of the absent benchmark information and hence dissimilar political decisions. In on-going social and health care reform process it is important that all adolescents should have equal access to mental health care.

Keywords: Adolescents, Mental health services, Child Welfare, Public sector service producers

Saapunut 23.3.2017

Hyväksytty 21.6.2017

\section{LÄHTEET}

(1) Paananen R, Merikukka M, Gissler M. Social determinants of mental health: a Finnish nationwide follow-up study on mental disorders. J Epidemiol Community Health 2012; 67(12):1025-31. https://doi.org/10.1136/jech-2013-202768

(2) Ristikari T, Törmäkangas L, Lappi, A ym. Suomi nuorten kasvuympäristönä - 25 vuoden seuranta vuonna 1987 Suomessa syntyneistä nuorista aikuisista. THL Raportteja 2016:9.

(3) Collishaw S, Maughan B, Goodman R ym. Time trends in adolescent mental health. J Child Psychol Psychiatry 2004; 45:8: 350-1362. https://doi.org/10.1111/j.14697610.2004.00335.x

(4) Webb M, Harden B. Beyond Child Protection - Promoting Mental Health for Children and Families in the Child Welfare System. Journal of Emotions and Behavioral Disorders 2003; 11:49-58. https://doi.org/10.1177/106342660301100107

(5) Thompson R, English D, Hawley K ym. The Influence of Family Environment on Mental Health Need and Service Use Among Vulnerable Children. Child Welfare 2007; 5(86):57-74.

(6) Pasanen T, Katajamäki K, Martikainen S. Lastensuojelun erityisyksikköön sijoitettujen lasten psykiatrinen oirehdinta, tarkkaavaisuus ja toimintakyky. Yhteiskuntapolitiikka 2015; 4(80); 349-364.
(7) Heino T, Hyry S, Ikäheimo S ym. Lasten kodin ulkopuolelle sijoittamisen syyt, taustat, palvelut ja kustannukset : HuosTa-hankkeen (20142015) päätulokset. THL 2016:3.

(8) Zwaanswijk M, Van der Ende M, Verhaak P ym. Factors Associated With Adolescent Mental Health Service Need and Utilization. J Am Acad Child Adolesc Psychiatry 2003; 6:42:692-700. https://doi.org/10.1097/01. CHI.0000046862.56865.B7

(9) Patel V, Flisher A, Hetrick S. Mental health of young people: a global public-health challenge. Lancet 2007; 369:1302-13. https://doi.org/10.1016/S0140-6736(07)60368-7

(10) Fortune S, Clarkson H. The role of child and adolescent mental health services in suicide prevention in New Zealand. Australian Psychiatry 2006; 4(14): 369-373. https://doi.org/10.1080/j.14401665.2006.02306.x

(11) Pirkola S, Sund R, \& Sailas E ym. Community mental-health services and suicide rate in Finland: a nationwide small-area analysis. Lancet 2009; 373: 147-153. https://doi.org/10.1016/S0140-6736(08)618486

(12) Wahlbeck K, Westman J, Nordentoft M ym. Outcomes of Nordic mental health systems: life expectancy of patients with mental disorders. $\mathrm{Br}$ J Psychiatry 2011; 199: 453-458. https://doi.org/10.1192/bjp.bp.110.085100 
(13) Durlak J. Primary prevention mental health programs for children and adolescents are effevctive. J Ment Health 1998; 5(7): 463-469. https://doi.org/10.1080/09638239817842

(14) McGorry P. The specialist youth mental health model: strengthening the weakest link in the public mental health system. MJA 2007; 7(187): 53-56.

(15) Zachrisson H, Rödje K, Mykletun A. Utilization of health services in relation to mental health problems in adolescents: A population based survey. BMC Public Health 2006; 6(34). https://doi.org/10.1186/1471-2458-6-34

(16) Alestalo A, Munnukka T, Pukuri T. Problems of young people in community psychiatric care. J Psychiatr Ment Health Nurs 2002; 9: 33-40. https://doi.org/10.1046/j.13510126.2001.00436.x

(17) Kontio R, Malin M, Joffe G. HUS-alueen mielenterveys- ja päihdepalvelut liian laitoskeskeisiä. Suomen lääkärilehti 2013; 7(68): 496-501a.

(18) Paananen R, Santalahti P, Merikukka M ym. Sosioeconomic and regional aspects in the use of specialized psychiatric care - a Finnish nationwide follow-up study. Eur J Public Health, 2012; 3(23): 372-377.

(19) Määttä A, Keskitalo E. Ulkoringiltä sisärinkiin. Kumuloituneista ongelmista kärsivät nuoret aikuiset pirstaleisessa palvelujärjestelmässä. Yhteiskuntapolitiikka 2014 2(79): 197-207.

(20) Aula M, Juurikkala V, Kalmari H ym. Lapsi- ja perhepalveluiden muutosohjelma. Kärkihanke. Sosiaali- ja terveysministeriön raportteja ja muistioita 2016:29.

(21) Ala-Nikkola T, Pirkola S, Kontio, R ym. Size Matters - Determinants of Modern, Community-Oriented Mental Health Services. Int J Environ Res Public Health 2014; 11: 8456-8474.

https://doi.org/10.3390/ijerph110808456
(22) Paananen R, Gissler M. Cohort Profile: The 1987 Finnish Birth Cohort. Int J Epidemiol 2012;41:941-945. https://doi.org/10.1093/ije/dyr035

(23) Salvador-Carulla L, Ruiz M, Romero C ym. Eurooppalainen mielenterveyspalveluiden kartoittamistyökalu. THL 2012: 5.

(24) Schneiderman J. Health issues of children in foster care. Contemporary Nurse 2003; 2(14): 123-128.

https://doi.org/10.5172/conu.14.2.123

(25) Sadeniemi M, Pirkola S, Pankakoski M, ym. Does Primary Care Mental Health Resourcing Affect the Use and Costs of Secondary Psychiatric Services? Int J Environ Res Public Health 2014; 11.

(26) Cleveland, W. S. (1979). Robust locally weighted regression and smoothing scatterplots, J Amer Statist Assoc 74(368): 829-836. https://doi.org/10.1080/01621459.1979.1048 1038

(27) Eriksson S \& Karppinen R. Kvantitatiivinen tutkimus Helsingin jälkihuoltonuorten toimintatahtoisuudesta ja palvelujen käytöstä asiakasasiakirjojen valossa vuosina 2013-15. Helsingin yliopisto 2016.

\section{Johanna Hedman}

VTM, sosiaalityöntekijä, väitöskirjatutkija

Helsingin yliopisto

MarJut VASTAMÄKI

Sairaanhoitaja (YAMK), apulaisosastonhoitaja HYKS Psykiatria

GRIGORI JOFFE

Psykiatrian dosentti, professori h.c., johtava yliläääri

Helsingin ja Uudenmaan sairaanhoitopiiri 